Penelitian

\title{
Isolasi dan Identifikasi Salmonella spp. pada Kloaka Kura-Kura Ambon (Cuora amboinensis)
}

\author{
(Isolation and Identification of Salmonella spp. in Cloaca of \\ Southeast Asian Box Turtle (Cuora amboinensis))
}

\author{
Fia Rahmatul Khair ${ }^{1}$, Erina ${ }^{2 *}$, Sugito ${ }^{3}$, M. Daud AK ${ }^{2}$ \\ ${ }^{1}$ Program Studi Pendidikan Dokter Hewan, Fakultas Kedokteran Hewan, Universitas Syiah Kuala \\ ${ }^{2}$ Laboratorium Mikrobiologi, Fakultas Kedokteran Hewan, Universitas Syiah Kuala \\ ${ }^{3}$ Laboratorium Klinik dan Bedah, Fakultas Kedokteran Hewan, Universitas Syiah Kuala \\ *Penulis untuk korespondensi: erina@unsyiah.ac.id \\ Diterima 20 April 2021, Disetujui 2 Oktober 2021
}

\begin{abstract}
ABSTRAK
Salmonellosis merupakan penyakit enterik yang disebabkan oleh berbagai jenis spesies Salmonella spp . Penelitian ini bertujuan untuk mengisolasi dan mengidentifikasi spesies Salmonella spp pada kloaka kura-kura ambon (Cuora amboinensis). Koleksi sampel dilakukan pada lima belas ekor kura-kura ambon yang berada di kota Banda Aceh dan sebagian Aceh Besar. Penelitian ini merupakan observasi lapangan dan eksperimental laboratorium berdasarkan metode Carter. Swab kloaka kura-kura ambon ditanam dalam media Selenite Cystine Broth (SCB) dan diinkubasikan selama 24 jam suhu $37^{\circ} \mathrm{C}$, jika terjadi perubahan warna menjadi orange dilanjutkan penanaman pada media Salmonella Shigella Agar (SSA). Koloni yang menunjukkan karakteristik Salmonella sp diamati warna, elevasi, ukuran, dan tepi secara makroskopik. Pewarnaan Gram dilakukan untuk pengamatan secara mikroskopis dan pengelompokan bakteri. Proses identifikasi Salmonella spp dilakukan dengan penanaman dalam media Indol, Methyl Red, Voges Proskauer, Sulfide Indole Motility (SIM), Simmons Citrate Agar (SCA), Triple Sugar Iron Agar (TSIA), uji biokimia (glukosa, sukrosa, laktosa, manitol, dan arabinosa). Penelitian ini dianalisis secara deskriptif dan disajikan dalam bentuk tabel dan gambar. Hasil penelitian ini menunjukkan bahwa pada lima belas sampel swab kloaka kura-kura ambon (100\%) positif Salmonella yang terdiri atas Salmonella bongori, Salmonella arizonae, Salmonella diarizonae, dan Salmonella indica. Oleh karena itu, dapat disimpulkan bahwa Salmonella bongori, Salmonella arizonae, Salmonella diarizonae, dan Salmonella indica dapat diisolasi dari kloaka kura-kura ambon.
\end{abstract}

Kata kunci : Foodborne disease, hewan eksotik, Salmonella spp., penyakit zoonosis

\begin{abstract}
Salmonellosis is an enteric disease caused by various types of Salmonella. This study aims to isolate and to identify Salmonella species in southeast asian box turtles. The sample collection was carried out on fifteen southeast asian box turtles around the Banda Aceh and Aceh Besar area. This study was a field observational and experimental laboratory based on Carter's method. Cloacal swabs were planted in Selenite Cystine Broth (SCB) and incubated for 24 hours at $37^{\circ}$ C. In case, the color turns to orange, it will be followed by planting on Salmonella Shigella Agar (SSA). The colony with Salmonella characteristic was observed macroscopically for color elevation, size, and edges. Gram staining is carried out for microscopic observation and bacterial grouping. Identification for Salmonella is planted in indole, methyl red, Voges Proskauer, sulfide indole motility (SIM), Simmons citrate agar (SCA), triple sugar iron agar (TSIA), and biochemistry test (glucose, sucrose, lactose, mannitol, and arabinose. This study was analyzed descriptively and presented in tables and figures. The results of this study indicate that fifteen of southeast asian box turtle (100\%) positive Salmonella consist of Salmonella bongori, Salmonella arizonae, Salmonella diarizonae, and Salmonella indica. Therefore, it can be concluded that Salmonella bongori, Salmonella arizonae, Salmonella diarizonae, and Salmonella indica can be isolated from the cloaca of southeast asian box turtle.
\end{abstract}

Keywords: exotic animals, food borne disease, Salmonella spp., zoonotic disease 


\section{PENDAHULUAN}

Salmonellosis merupakan penyakit yang disebabkan oleh berbagai spesies salmonella. Salmonellosis non-tifoid diderita oleh sekitar 200 juta sampai 1,3 miliar orang di seluruh dunia, dengan kematian 3 juta jiwa setiap tahun. Salmonellosis dapat ditularkan melalui beberapa hewan diantaranya, kuda, sapi, babi, dan reptil (Soedarto, 2012). Salmonella sp. dapat juga tersebar di lingkungan yang berhubungan dengan peternakan atau pembuangan tinja manusia. Penyakit salmonellosis berkembang di lingkungan dengan sanitasi kurang baik (Soeharsono, 2002).

Kura-kura merupakan salah satu peliharaan populer yang sering dihadiahkan untuk anak-anak. Selain dapat ditempatkan dalam kontainer berukuran kecil, tidak berisik, tidak menggigit, kura-kura juga hanya membutuhkan porsi makanan yang sedikit (William dan Heldson, 1965). Masyarakat lokal Indonesia memanfaatkan kura-kura darat atau turpepel sebagai salah satu sumber protein hewani. Pemanfaatan ini dilakukan terutama saat sumber protein hewani dari daging sapi atau ikan sulit didapatkan (Apriani et al., 2015). Kura-kura ambon (Cuora amboinensis) berpotensi sebagai sumber penularan penyakit salmonellosis pada manusia (Erina et al., 2019).

Kura-kura dan reptil lainnya merupakan reservoir salmonella (Kauffman dan Morrison, 1966; Marin et al., 2013) dan sering dikaitkan dengan kejadian salmonellosis pada manusia terutama anak-anak semenjak tahun 1963 berdasarkan laporan dari Hersey dan Mason. Pada tahun 1970-1971 terjadi hingga 280.000 kasus salmonellosis terkait kura-kura di USA (Lamm et al., 1972) dua belas kasus di New York (Ackman et al., 1995) 339 kasus antara 1990-2000 (Jong et al., 2005) dan 5.139 orang terinfeksi di Swedia (Ternhag et al., 2006). Salmonellae menjadi salah satu patogen paling penting di Inggris dan Wales dari tahun 1992-2000 (Adak et al., 2002). Sebuah penelitian di Jepang menunjukkan 130 dari 227 kurakura yang diteliti positif Salmonella enterica subsp. enterica. Hasil ini berpeluang menjadi wabah salmonellosis pada manusia terkait kepemilikan kura-kura (Kuroki et al., 2019). Terdapat dua dari empat puluh ekor reptil positif Salmonella sp. pada sebuah pet shop di Bogor (Arnafia et al., 2016) Semua sampel kura-kura yang dikoleksi dari pet shop yang berada di daerah Puerto Rico menunjukkan hasil positif Salmonella (Tauxe et al., 1985) 3,8\% dari 79 ekor kura-kura yang diteliti positif Salmonella di Kroasia. Peningkatan jumlah pemeliharaan reptil berbanding lurus dengan peningkatan kasus salmonellosis pada manusia (Gras et al., 2015; Lukac et al., 2015).

Infeksi Salmonella umumnya terjadi melalui foodborne, bahkan Salmonella sp. merupakan 90\% penyebab keracunan makanan di Inggris (Soeharsono, 2002). Namun, $11 \%$ infeksi Salmonella enterica dapat berasal dari hewan yang terpapar (Scallan et al., 2011; Hale et al., 2012; Bosch et al., 2016) dan lebih banyak menyerang anak-anak daripada orang dewasa (Angulo dan Swerdlow, 1995; Mermin et al., 1997; CDSUMMARY, 2008; Pickering et al., 2008). Salmonella dapat ditemukan di lingkungan tempat pemeliharaan reptil (Wikstrom et al., 2014; Yenni et al., 2017) dan telur kura-kura (Aoust et al., 1990; Shane et al., 1990; Mitchell et al., 2007), sehingga memelihara reptil berisiko terhadap kesehatan manusia maka penting bagi pihak berwenang untuk memberikan informasi kepada publik (Sa dan Solari, 2001). Tahun 1975, Food and Drug Administration (FDA) Amerika Serikat mengeluarkan aturan pelarangan penjualan dan pendistribusian kura-kura dengan ukuran karapas $<4$ inci atau $<10,16 \mathrm{~cm}$ (USFDA, 2019) peraturan pelarangan ini juga diterapkan pada sistem impor kura-kura di Kanada (Woodward et al., 1997).

Tahun 1996, dewan penasehat industri hewan peliharaan Amerika Serikat berkolaborasi dengan the Centers for Disease Control and Prevention (CDC) meluncurkan sebuah program pendidikan untuk pencegahan salmonellosis pada manusia terkait reptil (Bradley et al., 2001). Informasi mengenai keberadaan Salmonella sp. pada kloaka kura-kura masih sangat terbatas di Indonesia sehingga diperlukan penelitian untuk mendapatkan informasi sehingga dapat digunakan sebagai upaya pencegahan dan pengendalian salmonellosis pada manusia.

\section{BAHAN DAN METODE}

\section{Alat dan Bahan}

Alat-alat yang digunakan pada penelitian ini adalah cawan petri (Pyrex $\left.{ }^{\oplus}\right)$, object glass, tabung reaksi $\left(\right.$ Pyrex $\left.^{\circledR}\right)$, erlenmeyer glass (Pyrex $\left.{ }^{\circledR}\right)$, cotton swab steril, ose sengkelit, ose jarum, inkubator (Memmert $^{\text {TM }}$ ), mikroskop (Olympus ${ }^{\text {TM }}$ ), rak tabung reaksi, waterbath (Memmert ${ }^{\mathrm{TM}}$ ), hotplate $\left(\right.$ Heidolph $\left.^{\circledR}\right)$, timbangan digital $\left(\right.$ Ohaus $\left.^{\circledR}\right)$, sendok porselen, spatula, gelas ukur (Pyrex ${ }^{\circledR}$ ), lampu spiritus, kapas, pipet tetes, handscoon, tisu, termos es, dan masker.

Bahan yang digunakan dalam penelitian ini adalah alkohol $70 \%$, alkohol 96\%, methylen blue, safranin, lugol, akuades, crystal violet, salmonella shigella 
agar (Oxoid $\left.{ }^{\text {TW }}\right)$, selenite cystine broth (Oxoid ${ }^{\text {TM }}$ ), nutrient agar miring (Oxoid ${ }^{\text {TM }}$ ), bahan untuk uji IMVIC antara lain indol ( Difco $\left.^{\text {TM }}\right)$, methyl red (Oxoid $\left.{ }^{\text {Tm }}\right)$, voges proskauer (Oxoid $\left.{ }^{\text {TM }}\right)$, sulfide indole motility $\left(\mathrm{Oxoid}^{\mathrm{TM}}\right)$, Simmons citrate $\left(\mathrm{Oxoid}^{\mathrm{TW}}\right)$ ), triple sugar iron agar (Oxoid $^{\text {'m) }}$ ), media untuk uji uji biokimia (glukosa $\left(\right.$ Merck $\left.^{\text {TM }}\right)$, sukrosa $\left(\right.$ Merck $\left.^{\mathrm{T} M}\right)$, laktosa (Merck $\left.{ }^{\mathrm{TM}}\right)$, manitol $\left(\right.$ Merck $\left.^{\text {TM }}\right)$ dan arabinosa $\left(\right.$ Merck $\left.^{T M}\right)$ ), reagen Kovacs, reagen methyl red, reagen $\alpha$-Naphthol $5 \%, \mathrm{KOH}$ $40 \%$, dan minyak emersi.

\section{Metode Penelitian}

Penelitian ini merupakan observasi lapangan dan eksperimental laboratorium berdasarkan metode Carter 1987.

\section{Prosedur Penelitian}

\section{Pengambilan Sampel}

Sampel berasal dari swab kloaka kura-kura ambon yang diambil dengan swab steril. Selanjutnya, dimasukkan ke dalam tabung reaksi yang berisi Selenite Cystine Broth (SCB) dan diinkubasikan selama 24 jam pada suhu $37^{\circ} \mathrm{C}$.

\section{Isolasi dan Identifikasi Salmonella sp.}

Perubahan warna pada media SCB dapat diamati setelah 24 jam inkubasi. Hasil positif ditunjukkan dengan perubahan warna menjadi orange. Selanjutnya dilakukan penanaman pada media SSA dan diinkubasikan selama $24 \mathrm{jam}$ pada suhu $37^{\circ} \mathrm{C}$. Morfologi koloni yang tumbuh pada media SSA kemudian diamati dan selanjutnya dilakukan pewarnaan Gram. Identifikasi bakteri dilakukan dengan penanaman pada media Indol, Methyl Red, Voges Proskauer, Sulfide Indole Motility, Simmons Citrate (IMVIC) untuk media Methyl Red diinkubasikan selama 48 jam, Triple Sugar Iron Agar (TSIA), dan uji biokimia (glukosa, sukrosa, laktosa, manitol dan arabinosa) diinkubasikan pada suhu $37^{\circ} \mathrm{C}$ selama 24 jam.

\section{Analisis Data}

Data hasil pengamatan dianalisis secara deskriptif dan disajikan dalam bentuk tabel dan gambar.

\section{HASIL}

Hasil pengamatan pada media SCB menunjukkan perubahan warna media menjadi orange dan keruh (Gambar 1 dan Tabel 1). Hal ini sesuai dengan pernyataan Scharlau (2009) SCB merupakan media pengayaan untuk isolasi Salmonellae (Bailey et al., 1981). Penambahan cystine mengurangi toksisitas dari selenite terhadap mikroorganisme (Bridson, 2006) sehingga media menjadi selektif (Corry et al., 2003). Selanjutnya dila kukan penanaman bakteri pada media SSA. Pertumbuhan Salmonella pada media SSA biasanya ditandai dengan adanya koloni berbentuk bulat, pinggiran rata, tekstur rata, mengkilat, cembung, berukuran 2-3 mm dan bagian tengah berwarna hitam atau black center (Srianta dan Rinihapsari, 2003), karena adanya kombinasi tiosulfat dengan besi sebagai indikator pembentukan sulfida (Bridson, 2006). Pada penelitian ini diperoleh koloni bulat dan berwarna hitam dan dapat dilihat secara makroskopis pada Gambar 2.

Koloni yang berwarna hitam akan diamati morfologinya yang meliputi bentuk, ukuran, pigmentasi, permukaan, tepi, elevasi, dan aspek koloni. Hal ini dapat dilihat pada Tabel 2.

Selanjutnya dilakukan pewarnaan gram untuk memastikan bahwa bakteri tersebut termasuk ke dalam kelompok Gram negatif. Dari hasil pewarnaan Gram menunjukkan koloni berwarna merah muda dan berbentuk batang panjang. Hal ini sesuai dengan pernyataan White et al. (2000) bahwa Salmonella sp. merupakan bakteri Gram negatif. Hasil pewarnaan Gram dapat dilihat pada Gambar 3.

Bakteri diamati bentuk, warna, dan hasil pewarnaan Gram. Prinsip pewarnaan Gram berdasarkan kemampuan bakteri mempertahankan

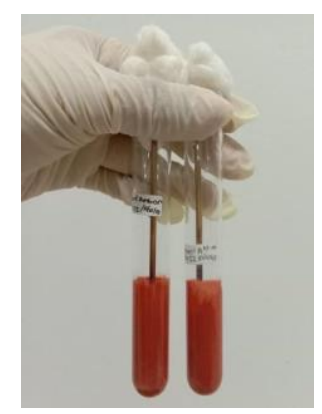

Gambar 1 Hasil pembiakan sampel pada SCB, terjadi perubahan warna menjadi orange 
166 | Khair et al.

Tabel 1 Hasil pengamatan pertumbuhan bakteri pada SCB

\begin{tabular}{cccc}
\hline No & Kode Sampel & Warna & Hasil \\
\hline 1 & KA1 & Orange & Positif \\
2 & KA2 & Orange & Positif \\
3 & KA3 & Orange & Positif \\
4 & KA4 & Orange & Positif \\
5 & KA5 & Orange & Positif \\
6 & KA6 & Orange & Positif \\
7 & KA7 & Orange & Positif \\
8 & KA8 & Orange & Positif \\
9 & KA9 & Orange & Positif \\
10 & KA10 & Orange & Positif \\
11 & KA11 & Orange & Positif \\
12 & KA12 & Orange & Positif \\
13 & KA13 & Orange & Positif \\
14 & KA14 & Orange & Positif \\
15 & KA15 & Orange & Positif \\
\hline
\end{tabular}

Tabel 2 Pengamatan morfologi Salmonella spp. yang tumbuh pada media SSA

\begin{tabular}{|c|c|c|c|c|c|c|c|c|}
\hline No & $\begin{array}{l}\text { Kode } \\
\text { Sampel }\end{array}$ & Bentuk & Ukuran & Pigmentasi & Permukaan & Tepi & Elevasi & $\begin{array}{l}\text { Aspek Ko- } \\
\text { loni }\end{array}$ \\
\hline 1 & KA1 & Bulat & $1 \mathrm{~mm}$ & Hitam & Halus & Rata & Cembung & Mengkilap \\
\hline 2 & $\mathrm{KA} 2$ & Bulat & $1 \mathrm{~mm}$ & Hitam & Halus & Rata & Cembung & Mengkilap \\
\hline 3 & $\mathrm{KA} 3$ & Bulat & $1,5 \mathrm{~mm}$ & Hitam & Halus & Rata & Cembung & Mengkilap \\
\hline 4 & KA4 & Bulat & $1 \mathrm{~mm}$ & Hitam & Halus & Rata & Cembung & Mengkilap \\
\hline 5 & KA5 & Bulat & $1 \mathrm{~mm}$ & Hitam & Halus & Rata & Cembung & Mengkilap \\
\hline 6 & KA6 & Bulat & $1,5 \mathrm{~mm}$ & Hitam & Halus & Rata & Cembung & Mengkilap \\
\hline 7 & KA7 & Bulat & $2 \mathrm{~mm}$ & Hitam & Halus & Rata & Cembung & Mengkilap \\
\hline 8 & KA8 & Bulat & $1 \mathrm{~mm}$ & Hitam & Halus & Rata & Cembung & Mengkilap \\
\hline 9 & KA9 & Bulat & $1 \mathrm{~mm}$ & Hitam & Halus & Rata & Cembung & Mengkilap \\
\hline 10 & KA10 & Bulat & $1 \mathrm{~mm}$ & Hitam & Halus & Rata & Cembung & Mengkilap \\
\hline 11 & KA11 & Bulat & $1 \mathrm{~mm}$ & Hitam & Halus & Rata & Cembung & Mengkilap \\
\hline 12 & KA12 & Bulat & $2 \mathrm{~mm}$ & Hitam & Halus & Rata & Cembung & Mengkilap \\
\hline 13 & KA13 & Bulat & $1 \mathrm{~mm}$ & Hitam & Halus & Rata & Cembung & Mengkilap \\
\hline 14 & KA14 & Bulat & $1 \mathrm{~mm}$ & Hitam & Halus & Rata & Cembung & Mengkilap \\
\hline 15 & KA15 & Bulat & $2 \mathrm{~mm}$ & Hitam & Halus & Rata & Cembung & Mengkilap \\
\hline
\end{tabular}

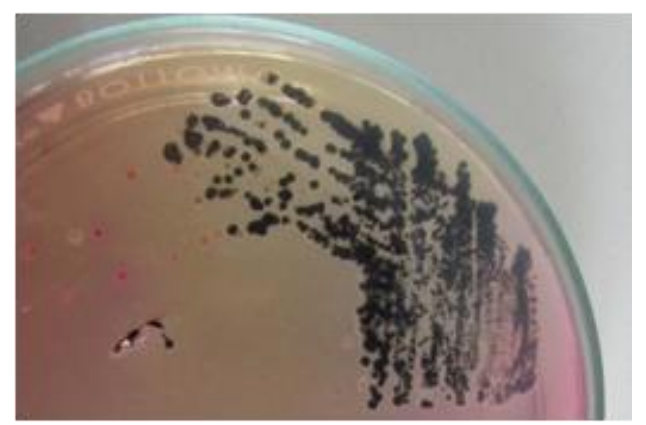

Gambar 2 Hasil pembiakan Salmonella spp. pada SSA 
kompleks kristal violet-iodine setelah diberikan alkohol 96\% (Kleuring, 2001). Salmonella memiliki lapisan peptidoglikan yang tipis dan membran luar terdiri dari polisakarida sehingga mudah dihancurkan oleh sistem imun dan kehilangan warna violet saat pewarnaan Gram (Brands, 2006). Pengamatan secara mikroskopis hasil pewarnaan Gram dapat dilihat pada Tabel 3.

Bakteri akan diidentifikasi dengan melakukan uji IMVIC dan biokimia yang dapat dilihat pada Gambar 4 dan Tabel 4.

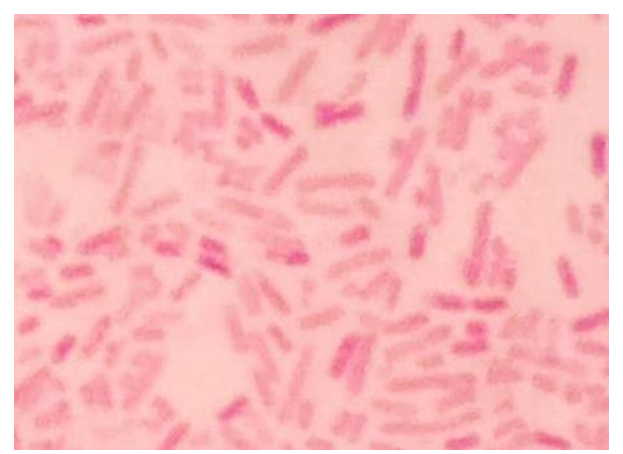

Gambar 3 Hasil pewarnaan Gram Salmonella spp. Diamati menggunakan mikroskop dengan pembesaran (1000x)

Tabel 3 Pengamatan secara makroskopis hasil pewarnaan Gram

\begin{tabular}{ccccc}
\hline No & Kode Sampel & Bentuk & Warna & Kelompok Gram \\
\hline 1 & KA1 & Batang Panjang & Merah Muda & Negatif \\
2 & KA2 & Batang Panjang & Merah Muda & Negatif \\
3 & KA3 & Batang Panjang & Merah Muda & Negatif \\
4 & KA4 & Batang Panjang & Merah Muda & Negatif \\
5 & KA5 & Batang Panjang & Merah Muda & Negatif \\
6 & KA6 & Batang Panjang & Merah Muda & Negatif \\
7 & KA7 & Batang Panjang & Merah Muda & Negatif \\
8 & KA8 & Batang Panjang & Merah Muda & Negatif \\
9 & KA9 & Batang Panjang & Merah Muda & Negatif \\
10 & KA10 & Batang Panjang & Merah Muda & Negatif \\
11 & KA11 & Batang Panjang & Merah Muda & Negatif \\
12 & KA12 & Batang Panjang & Merah Muda & Negatif \\
13 & KA13 & Batang Panjang & Merah Muda & Negatif \\
14 & KA14 & Batang Panjang & Merah Muda & Negatif \\
15 & KA15 & Batang Panjang & Merah Muda & Negatif \\
\hline
\end{tabular}

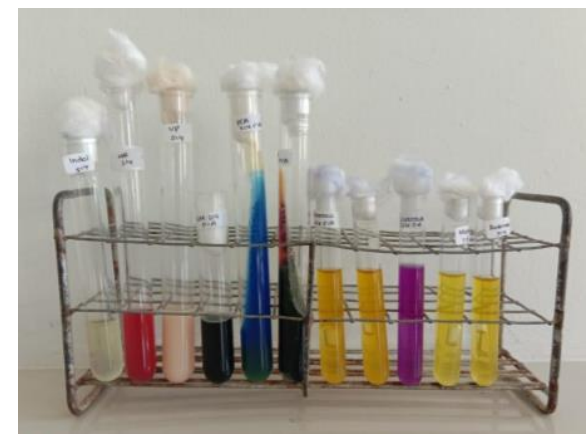

Gambar 4 Hasil uji IMVIC dan uji biokimia. 1) Indol, 2) Methyl Red, 3) Voges Proskauer, 4) Sulfide Indole Motility (SIM), 5) TSIA, 7) Glukosa, 8) Sukrosa, 9) Laktosa, 10) Manitol, 11) Arabinosa 
Tabel 4 Pengamatan hasil uji IMVIC dan biokimia

\begin{tabular}{|c|c|c|c|c|c|c|c|c|c|c|c|c|}
\hline No & $\begin{array}{l}\text { Kode } \\
\text { Sampel }\end{array}$ & Indol & $M R$ & VP & SIM & SCA & TSIA & $G$ & $\mathrm{~S}$ & L & $\mathrm{Mn}$ & A \\
\hline 1 & $\mathrm{KA} 1$ & - & + & - & $\mathrm{M} / \mathrm{H}_{2} \mathrm{~S}$ & + & $\mathrm{B} / \mathrm{H}_{2} \mathrm{~S} / \mathrm{g}$ & $+/ g$ & - & $(-)$ & $+/ g$ & $+/ g$ \\
\hline 2 & $\mathrm{KA} 2$ & - & + & - & $\mathrm{M} / \mathrm{H}_{2} \mathrm{~S}$ & + & $\mathrm{B} / \mathrm{H}_{2} \mathrm{~S} / \mathrm{g}$ & $+/ g$ & - & $(-)$ & $+/ g$ & $+/ g$ \\
\hline 3 & $\mathrm{KA} 3$ & - & + & - & $\mathrm{M} / \mathrm{H}_{2} \mathrm{~S}$ & + & $\mathrm{B} / \mathrm{H}_{2} \mathrm{~S} / \mathrm{g}$ & $+\lg (+)$ & - & - & $+/ g$ & $+/ g$ \\
\hline 4 & $\mathrm{KA} 4$ & - & + & - & $\mathrm{M} / \mathrm{H}_{2} \mathrm{~S}$ & $(+)$ & $\mathrm{A} / \mathrm{H}_{2} \mathrm{~S} / \mathrm{g}$ & $+\lg$ & - & - & $+/ g$ & $+/ g$ \\
\hline 5 & KA5 & - & + & - & $\mathrm{M} / \mathrm{H}_{2} \mathrm{~S}$ & + & $\mathrm{A} / \mathrm{H}_{2} \mathrm{~S} / \mathrm{g}$ & $+\lg (+)$ & - & - & $+/ g$ & $+/ g$ \\
\hline 6 & KA6 & - & + & - & $\mathrm{M} / \mathrm{H}_{2} \mathrm{~S}$ & + & $\mathrm{A} / \mathrm{H}_{2} \mathrm{~S} / \mathrm{g}$ & $+/ g$ & - & $(-)$ & $+/ g$ & $+/ g$ \\
\hline 7 & KA7 & - & + & - & $\mathrm{M} / \mathrm{H}_{2} \mathrm{~S}$ & + & $\mathrm{B} / \mathrm{H}_{2} \mathrm{~S} / \mathrm{g}$ & $+\lg (+)$ & - & - & $+/ g$ & $+/ g$ \\
\hline 8 & KA8 & - & + & - & $\mathrm{M} / \mathrm{H}_{2} \mathrm{~S}$ & + & $\mathrm{A} / \mathrm{H}_{2} \mathrm{~S} / \mathrm{g}$ & $+/ g$ & - & $(-)$ & $+/ g$ & $+/ g$ \\
\hline 9 & KA9 & - & + & - & $\mathrm{M} / \mathrm{H}_{2} \mathrm{~S}$ & + & $\mathrm{A} / \mathrm{H}_{2} \mathrm{~S} / \mathrm{g}$ & $+\lg (+)$ & - & - & $+/ g$ & $+\lg$ \\
\hline 10 & KA10 & - & + & - & $\mathrm{M} / \mathrm{H}_{2} \mathrm{~S}$ & $(+)$ & $\mathrm{B} / \mathrm{H}_{2} \mathrm{~S} / \mathrm{g}$ & $+\lg$ & - & - & $+\lg$ & $+\lg$ \\
\hline 11 & KA11 & - & + & - & $\mathrm{M} / \mathrm{H}_{2} \mathrm{~S}$ & + & $\mathrm{A} / \mathrm{H}_{2} \mathrm{~S} / \mathrm{g}$ & $+\lg (+)$ & - & - & $+/ g$ & $+/ g$ \\
\hline 12 & KA12 & - & + & - & $\mathrm{M} / \mathrm{H}_{2} \mathrm{~S}$ & + & $\mathrm{A} / \mathrm{H}_{2} \mathrm{~S} / \mathrm{g}$ & $+\lg (+)$ & - & $(+)$ & $+/ g$ & $+/ g$ \\
\hline 13 & KA13 & - & + & - & $\mathrm{M} / \mathrm{H}_{2} \mathrm{~S}$ & + & $\mathrm{A} / \mathrm{H}_{2} \mathrm{~S} / \mathrm{g}$ & $+/ g$ & - & $(-)$ & $+\lg$ & $+\lg$ \\
\hline 14 & KA14 & - & + & - & $\mathrm{M} / \mathrm{H}_{2} \mathrm{~S}$ & + & $\mathrm{B} / \mathrm{H}_{2} \mathrm{~S} / \mathrm{g}$ & $+/ g$ & - & $(+)$ & $+/ g$ & $+/ g$ \\
\hline 15 & KA15 & - & + & - & $\mathrm{M} / \mathrm{H}_{2} \mathrm{~S}$ & + & $\mathrm{A} / \mathrm{H}_{2} \mathrm{~S} / \mathrm{g}$ & $+/ g$ & - & $(-)$ & $+\lg$ & $+/ g$ \\
\hline
\end{tabular}

\section{PEMBAHASAN}

Uji indol bertujuan untuk melihat kemampuan organisme mendegradasi asam amino triptofan dan menghasilkan indol dengan menggunakan enzim triptopanase yang dapat dideteksi dengan penambahan reagen Kovacs (Hemraj et al., 2013) hasil positif ditandai dengan terbentuknya cincin pink kemerahan (cherry-red ring) pada permukaan media (Williams, 2009). Hasil penelitian diperoleh hasil negatif karena dari kelima belas sampel tidak menunjukkan adanya cincin berwarna merah setelah penambahan reagen Kovacs. Hal ini sesuai dengan pernyataan Boland (2013) bahwa spesies Salmonella menunjukkan hasil negatif untuk uji indol.

Uji Methyl Red (MR) bertujuan untuk melihat kemampuan organisme menghasilkan dan mempertahankan produk asam yang stabil sebagai hasil akhir dari fermentasi glukosa. Methyl Red (MR) akan berwarna merah sebagai hasil positif dan kuning sebagai hasil negatif (Tille, 2017). Dari kelima belas sampel diperoleh hasil yang positif yaitu ditandai dengan terjadinya perubahan warna indikator menjadi merah. Hal ini sesuai dengan dengan pernyataan Pervical dan Williams (2014) bahwa Salmonella menunjukkan hasil positif untuk uji Methyl Red (MR).

Uji Voges Proskauer (VP) bertujuan untuk melihat kemampuan organisme untuk mengubah produk asam menjadi acetoin dan 2,3-butadienol. menggunakan reagen $\alpha$-naphthol dan $\mathrm{KOH} 40 \%$, hasil positif ditunjukkan dengan terbentuknya warna merah pada media (Tille, 2017). Hasil uji Voges Proskauer (VP) kelima belas sampel menunjukkan hasil negatif sesuai dengan pernyataan Pervical dan Williams (2014) bahwa Salmonellae menunjukkan hasil negatif untuk uji Voges Proskauer (VP).

Uji Sulfide Indole Motility (SIM) bertujuan mengetahui pergerakan bakteri (Hadioetomo,1985). Media ini mengandung ferrous ammonium sulfate and sodium thiosulfate yang merupakan indikator pembentukan hydrogen sulfide $\left(\mathrm{H}_{2} \mathrm{~S}\right)$. Hasil positif adanya $\mathrm{H}_{2} \mathrm{~S}$ ditandai dengan menghitamnya medium yang telah diinokulasikan, sedangkan hasil positif adanya motilitas adalah melebarnya zona difusi pertumbuhan dari garis inokulasi (Hardy, 1996). Dari hasil uji SIM didapati semua sampel positif menghasilkan $\mathrm{H}_{2} \mathrm{~S}$ dan bersifat motil. Hal ini sesuai dengan pernyataan McHan (2014) bahwa Salmonella merupakan bakteri yang motil dan dapat menghasilkan gas $\mathrm{H}_{2} \mathrm{~S}$.

Uji Simmons Citrate Agar digunakan untuk membedakan antara famili Enterobacteriaceae dan kelompok Aerogenes berdasarkan pemanfaatan sitrat sebagai satu-satunya sumber karbon (Himedia, 2019) Hasil positif uji Simmons Citrate ditunjukkan dengan perubahan media menjadi warna biru (Haque dan Sao, 2015) karena adanya indikator bromthymol blue (Apelabi et al., 2015). Hasil uji Simmons Citrate 
Agar untuk kelima belas sampel menunjukkan hasil positif dimana warna media berubah dari hijau menjadi biru. Hal ini sesuai dengan pernyataan Himedia (2019) bahwa Salmonella akan menunjukkan reaksi positif pada uji Simmons Citrate Agar.

Uji Triple Sugar Iron Agar (TSIA) bertujuan untuk melihat kemampuan bakteri memfermentasi glukosa dan/atau laktosa dan kemampuan untuk menghasilkan gas $\mathrm{H}_{2} \mathrm{~S}$. TSIA mengandung tiga biokimia yaitu glukosa, sukrosa dan laktosa. Hasil positif ditunjukkan dengan perubahan media menjadi kuning karena adanya produksi asam. Salmonella pada TSIA akan membuat bagian slant berubah menjadi merah, dan bottom menjadi kuning. Apabila dihasilkan $\mathrm{H}_{2} \mathrm{~S}$ maka akan bereaksi dengan ferrous sulfate (III) dan terbentuk presipitasi hitam dari ferric sulfide FeS (II) di bagian bottom (Midorikawa, 2014). Hasil uji TSIA menunjukkan bahwa semua sampel menghasilkan $\mathrm{H}_{2} \mathrm{~S}$ dan menghasilkan ferric sulfide. Sampel yang memiliki slant bewarna kuning (KA4, KA5, KA6, KA8, KA9, KA11, KA12, KA13, dan KA15) akan membuat media menjadi asam sebagai hasil fermentasi laktosa oleh beberapa spesies Salmonella.

Uji biokimia yang digunakan pada penelitian ini terdiri dari glukosa, laktosa, sukrosa, laktosa, manitol, dan arabinosa yang b ertujuan untuk melihat kemampuan bakteri memfermentasi gula tersebut. Salmonella dapat memfermentasi glukosa, manitol dan sorbitol serta menghasilkan gas (Boland, 2013; Percival dan Williams, 2013).

Genus Salmonella meliputi dua spesies yaitu $S$. enterica dan S. bongori. Subdivisi S. enterica terdiri dari 6 subspesies yaitu: enterica, salamae, arizonae, diarizonae, houtenae, dan indica (Gay et al., 2014). Salmonella bongori terbatas pada hewan berdarah dingin, sementara Salmonella enterica dapat menginfeksi berbagai jenis hewan berdarah panas (Pasmans et al., 2002; Mansfield dan Fox, 2019).

Beberapa jenis Salmonella yang dapat diisolasi dari reptil yaitu: Salmonella bongori (Dieckmann et al., 2008), Salmonella arizonae dan Salmonella diarizonae yang merupakan pathogen utama penyebab reptile associated salmonellosis (RAS) (Pederson et al., 2009), Salmonella indica (Brenner et al, 2000; Grimont dan Weill, 2007; DBITE, 2015), Salmonella houtenae, dan Salmonella salamae (DBITE, 2015).

Fermentasi laktosa merupakan salah satu prinsip dasar dalam membedakan jenis Salmonella (Bonke et al., 2012; Alexan, 2017), sebab hanya beberapa spesies saja yang mampu memfermentasi gula ini (Latif et al., 2014; Alexan, 2017). Jenis Salmonella yang mampu memfermentasi laktosa, yaitu: Salmonella arizonae dan Salmonella diarizonae, sementara Salmonella indica menunjukkan hasil dubius untuk fermentasi laktosa (Grimont dan Weill, 2007; DBITE, 2015). Perbedaan kemampuan fermentasi laktosa ini terjadi akibat beberapa strain memfermentasi laktosa dalam kurun waktu 48 jam (hingga 15\%). Kehadiran $\mathrm{H}_{2} \mathrm{~S}$ juga merupakan salah satu kunci diagnostik dalam tes screening Salmonella (Winn et al., 2006). Hasil penelitian diperoleh sampel yang mampu memfermentasi laktosa dan menghasilkan $\mathrm{H}_{2} \mathrm{~S}$ (KA1, KA2, KA6, KA8, KA12, KA13, KA14, dan KA15) yang mengarah kepada Salmonella arizonae, Salmonella diarizonae, dan Salmonella indica. Subspesies arizonae dan diarizonae menunjukkan hasil indol negatif, MR positif, motil, sitrat positif, dan mampu memfermentasi glukosa, manitol, arabinosa, laktosa, dan tidak memfermentasi sukrosa (DBITE, 2015). Hal ini menyulitkan untuk membedakan kedua Salmonella ini, sehingga membutuhkan uji lanjutan seperti uji sensitivitas antibiotik menggunakan bioMérieux VITEK $^{\oplus} 2$ system untuk mengkonfirmasi jenis subspesies (Bella et al., 2011).

Jenis Salmonella yang tidak dapat memfermentasi laktosa antara lain: Salmonella bongori, Salmonella houtenae, dan Salmonella salamae (Grimont dan Weill, 2007; DBITE, 2015) Sampel negatif fermentasi laktosa (KA3, KA4, KA5, KA7, KA9, KA10, dan KA11) dapat mengarah pada subspesies tersebut. Salmonella houtenae menunjukkan hasil dubius fermentasi arabinosa dan Salmonella salamae menunjukkan hasil positif uji indol (DBITE, 2015), sehingga kedua subspesies ini tidak termasuk dalam hasil penelitian dimana Salmonella mampu memfermentasi arabinosa (90-100\%) dan menunjukkan hasil negatif uji indol.

Infeksi Salmonella bongori dapat menyebabkan penyakit sistemik pada manusia (Chan et al., 2003) dan enteritis akut pada anak-anak (Giammanco et al., 2002) tetapi kasus ini jarang ditemukan (Fokes et al., 2011).

Infeksi Salmonella arizonae dapat terjadi pada host immunocompromissed dan akibat kontak dengan reptil (Bella et al., 2011) seperti iguana, kurakura, dan ular (Pedersen et al., 2009; Gunal dan Erdem, 2014), biasanya berpredileksi di usus reptil (Mahajan et al., 2003).

Salmonella diarizonae dapat diisolasi reptil terutama ular (Schroter et al., 2004). Menurut Horvath et al. (2016) Salmonella ini dapat menimbulkan rasa sakit pada sinus frontalis, menginfeksi testis dan epididimis pada kambing Ferreras et al., 2007), dan berkolonisasi pada mukosa hidung domba (Lacasta et al., 2012). 
Kasus Reptile Associated Salmonellosis (RAS) pada manusia terjadi karena 50-90\% reptil membawa Salmonella spp. Gejala yang ditimbulkan berupa gangguan gastrointestinal $69-78 \%$, penyakit invasif 15\%, dan meningitis 5-14\% (Briard dan Retornaz, 2015). Persentase Salmonella yang tinggi pada reptil berisiko untuk terjadinya transmisi dan infeksi ke manusia dan hewan lainnya (Geue dan Loschner, 2002).

Kura-kura sehat membawa Salmonella spp. sebagai flora normal dalam ususnya dan dikeluarkan bersama feses (Pasmans et al., 2002; Bosch et al., 2016; Yenni et al., 2017), sehingga memelihara kurakura berpotensi menularkan Salmonella kepada manusia dan hewan lain seperti anjing dan kucing (Su dan Chiu, 2007). Kontak dengan hewan merupakan rute transmisi bagi kebanyakan patogen enterik. Usaha pencegahan transmisi patogen dari hewan ke manusia memerlukan kesadaran akan kebersihan dan higienitas (Hale et al., 2012).

Berdasarkan hasil penelitian disimpulkan bahwa pada kloaka kura-kura ambon (Cuora amboinensis) dapat ditemukan beberapa jenis Salmonella seperti Salmonella bongori, Salmonella arizonae, Salmonella diarizonae, dan Salmonella indica.

"Penulis menyatakan tidak ada konflik kepentingan dengan pihak-pihak yang terkait dalam penelitian ini".

\section{DAFTAR PUSTAKA}

Ackman DM, Drabkin P, Birkhead G, Cieslak P. 1995. Reptile-associated salmonellosis in New York state. $\quad$ Pediatr Infect. Dis. J., 14(11): 955-956.

Adak GK, Long SM, Brien SJO. 2002. Trends in indigenous foodborne disease and deaths, England and Wales: 1992 to 2000. Gut, 51: 832-838.

Alexan AF. 2017. Lactose fermenting Salmonella typhimurium, Salmonella Stratford and Salmonella blegdam. Egypt. J. Agric. Res., 95(3): 1285-1297.

Angulo FJ, Swerdlow DL. 1995. Bacterial enteric infections in persons infected with human immunodeficiency virus. CID, 21 Suppl 1:84.

Aoust JYD, Daley E, Crozier M, Sewell, AM. 1990. Pet turtle : a continuing international threat to public health. Am. J. Epidemiol., 132(2): 233-234.

Apelabi PC, Wuri DA, Sanam MUE. 2015. Perbandingan nilai total plate count (TPC) dan cemaran Salmonella sp pada ikan tongkol (Eutynnus sp.) yang dijual di tempat pelelangan ikan (TPI), pasar tradisional dan pedagang ikan eceran di Kota Kupang. J. Kaji. Vet., 3(2): 121-137.

Apriani D, Badaruddin E, Latupapua L. 2015. Jenis, perilaku, dan habitat turtepel (Cuora amboinensis amboinensis) di sekitar sungai Wairuapa Desa Waimital, Kecamatan Kairatu, Seram bagian barat. JHT, 3(2):179-181.

Arnafia W, Ningrum SG, Adji RS, Lukman DW, Pasaribu FH, Wibawan IWT. 2016. Isolasi of Salmonella from reptiles in pet shop and its susceptibility to antibiotics in Indonesia. Inter. J. Bioflux Soc., 8(4): $\quad$ 177-178.

Bailey JS, Cox NA, Thomson JE. 1981. Efficiency of selenite cystine and tt enrichment broths for detection of Salmonella. J. App. Bacteriol., 51: 409-410.

Bella SD, Capone A, Bordi E, Johnson E, Musso, M, Topino S, Noto P, Petrosillo N. 2011. Salmonella enterica ssp. arizonae infection on a 43-years old italian man with hypoglobulinemia: a case report and review of the literature. J. Med. Case Repotrs, 5:1-3.

Boland S. 2013. Identification of Salmonella spesies. UK Standards for Microbiology investigatios, London.

Bonkey R, Wacheck S, Bumann C, Thum C, Stuber E, Konig M, Stephan R, Ahomma MF. 2012. High prevalence of Salmonella enterica subsp. diarizonae in tonsils of ship at slaughter. Food Research International, 45:880-883.

Bosch S, Tauxe RB, Behravesh CB. 2016. Turtle associated salmonellosis, united states, 2006-2014. Emerg. Infect. Dis., 22 (7): 1149-1150.

Bradley T, Angulo F, Mitchell M. 2001. Public health education on Salmonella spp and reptiles. JAVMA, 219(6): 754-755.

Brands, D.A. 2006. Salmonella. Chelsea House Publisher, USA.

Brenner FW, Villar RG, Angulo FJ, Tauxe R,Swaminathan B. 2000. Salmonella Nomenclature. J. Clin. Microbiol., $\quad$ 38(7): 2465-2466.

Briad E, Retornaz K. 2015. Salmonella enterica subsp. arizonae meningitis in a neonate exposed to a corn snake. Pediatric Infect. Dis. J., 34(10): 1143-1144.

Bridson EY. 2006. The Oxoid Manual. 9th ed. Oxoid Limeted, England.

CDSUMMARY. 2008. Salmonellosis and campylobacteriosis in infants. DHS, 57(22): 1-2.

Chan K, Baker S, Kim CC, Detweiler CS, Dougan G, Falkow S. 2003. Genomic comparison of Salmonella bongori by use of an S. enterica serovar typhimurium dna microarray. J. Bacteriol., 185(2): 553-554.

Corrente M, Totaro M, Martella V, Campolo M, Lorusso $A$, Ricci $M$, Buonavoglia C. 2006. Reptile 
associated salmonellosis in man, Italy. Emerg. Infect. Dis., 12(2): 358.

Corry JEL, Curtis GDW, Baird RM. 2003. Handbook of Culture Media for Food Microbiology, Second Edition, Volume 37. Elsevier Science, UK.

DBITE. 2015. Database of Biochemical Tests of Pathogenic Enterobacteriaceae Family. BISR, Jaipur.

Dieckmann R, Helmunth R, Erhard M, Malorny, B. 2008. Rapid calssification and identification of Salmonellae at the spesies and subspecies levels by whole cell matrix-assisted laser desorption ionization-time of flight mass spectrometry. Appl. Environ.Microbiol, 74(24):7767-7768.

Erina, Karunita D, Amalia S, Fakhrurrazi, Ismail, Hennivanda. 2019. Deteksi Salmonella sp pada saluran pencernaan kura-kura ambon (Cuora amboinensis). Jimvet, 3(2): 55-57.

Ferreras MDC, Munoz M. Perez V, Benavides J, Pariente CG, Fuertes M, Aduriz G, Marin JFG. 2007. Unilateral orchitis and epididymitis caused by

Salmonella enterica subspecies diarizonae infection in ram. J. Vet. Diagn. Invest., 19:194-197.

Fokes M, Schroeder GN, Langridge GC, Blondel CJ, Mammina C, Connor TR, Smith HS, Vernikos GS, Robinson KS, Sanders M, Petty NK, Kingsley RA, Baumler AJ, Nuccio SP, Contreras I, Santiviago CA, Maskell D, Barrow P, Humphrey T, Nastasi A, Roberts M, Frankel G, Parkhill J, Dougan G, Thomson NR. 2011. Salmonella bongori provides insights into the evolution of the Salmonellae. Plos Pathogen, 7(8): 1-2.

Gay N, Simon LH, Francois XW, Benoit DT, Franck B. 2014. Salmonella serotypes in reptiles and humans, french guaina. Vet. Microbiol., 170(2): 167-169.

Giammanco GM, Pignato S, Mammina C, Grimont F, Grimont PAD, Nastasi A, Giammanco G. 2002. Persistent endemicity of Salmonella bongori 48:z35:-in Southern Italy: molecular characterization of human, animal, and enviromental isolates. J. Clin. Microbiol., 40(9): 3502-3504.

Gras LM, Heck M, Pelt WV. 2015. Increase in reptileassociated human salmonellosis and shift toward adulthood in the age groups at risk, the Netherlands, 1985 to 2014. Euro Surveill, 21(34): 1-4.

Grimont PAD, Weil FX. 2007. Antigenic Formulae of The Salmonella Serovars. 9th Edition. Institut Pasteur, France.

Gunal E, Erdem H. 2014. Detection of Salmonella arizonae in an enteric fever outbreak by the id 32 gn automated. Inter. J. Infect. Dis., 215:176-177.

Hadioetomo RS. 1985. Mikrobiologi Dasar dalam Praktek Teknik dan Prosedur Dasar Laboratorium Gramedia, Jakarta.
Hale $C R$, Scallan E, Cronquist AB, Dunn J, Smith K, Robinson T, Lathrop S, Angelo MTD, Clogher P. 2012. Estimates of enteric illness attributable to contact with animals and their enviroments in united states. J. Clin. Infect. Dis., 54 Suppl 5:472479.

Haque SE, Sao S. 2015. Isolation and identification of microorganisms from different soil samples of Bilaspur. World J. Pharma. Res., 4(6): 20432046.

Hardy. 1996. SIM (Sulfide, Indole, Motility) Medium. Hardy Diagnostics, US.

Hemraj V, Diksha S, Avneet G. 2013. A review of commonly used biochemical test for bacteria. Innovare J. Life Sci., 1(1): 1-7.

Himedia. 2019. Technical Data. Simmons Citrate Agar. Himedia laboratories, India.

Horvath L, Kraft M, Fostiropoulos K, Falkowski A, Tarr PE. 2016. Salmonella enterican subspecies diarizonae maxillary sinusitis in a snake handler: first report. Open Forum Infectious Disease, Oxford University Press.

Jong BD, Andersson Y, Ekdahl K. 2005. Effect of regulation and education on reptile associated salmonellosis. Emerg. Infect. Dis., 11(2): 398-402.

Kauffmann AF, Morrison ZL. 1966. An epidemiologic study of salmonellosis in turtle. Am. J. Epidemiol., 84(2): 364-366.

Kleuring G. 2001. Gram Stain Technique. Protocol of Molecular Cell Physiology, US.

Kuroki T, Ishihara T, Nakajima N, Furukawa I, Une Y. 2019. Prevalence of Salmonella enterica subsp. Enterica in red-eared sliders (Trachemys scripta elegans) retailed in pet shops in Japan. Jpn. J. Infect. Dis., 72: 38-42.

Lacasta D, Ferrer LM, Ramos JJ, Bueso JP, Borobia $M$, Arcaute MRD, Figueras $L$, Sainz JMG, Heras MDL. 2012. Chronic proliferative rhinitis associated with Salmonella enterica subspecies diarizonae serovar 61:k:1, 5, (7) in sheep in Spain. J. Comp. Path, 147: 406-409.

Lamn SH, Taylor AJ, Gangarosa EJ, Anderson HW, Young W, Clark MH, Bruce AR. 1972. Turtledassociated salmonellosis. Am. J. Epidemiol., 95(6): 511.

Lukac M, Pedersen K, Radovcic E P. 2015. Prevalence of Salmonella in captive reptiles from Croatia. J. Zoo Wildlife Med., 46(2): 234-236.

Mahajan RK, Khan SA, Chandel DS, Kumar N, Hans C, Chaudhry R. 2003. Fatal case of Salmonella enterica subsp. arizonae gastroenteritis in an infant with microcephaly. J. Clin. Microbiol., 41(12): 5830-5832. 
Mansfield KG dan Fox JG. 2009. Bacterial disease. Common Marmoset Captiv Biomed Res, 10.1016/B978-0-12- 811829-0.00016-9.

Marin C, Capaccioni SI, Bodi SG, Jimenez FM, Vega S. (2013). Free-living turtles are a reservoir for Salmonella but not Campylobacter. PLOS, 8(8): 1-3.

McHan. 2014. Sulfid Indole Motility Medium. Dalynn Biologicals, Catalogue No. TS58.

Mermin J, Hoar B, Angulo FJ. 1997. Iguanas and Salmonella marina infection in childern: a reflection of increasing incidence of reptileassociated salmonellosis in the united states. Pediatrics, 99(3): 399-340.

Mermin J, Hutwagner L, Vugia D, Swallow S, Daily P, Bender J, Koehler RM, Angulo, FJ. (2004). Reptiles, amphibians, and human Salmonella infection: a population-based, case- control study. CID, Suppl 3; S253-61.

Midorikawa Y, Nakamura S, Phetsouvanh R, Midorikawa K. 2014. Detection of non typhoidal Salmonella using a mechanism for controlling hydrogen sulfide production. Open J. Med. Microbiol., 4: 90-91.

Mitchell MA, Adamson TW, Singleton CB, Roundtree MK, Bauer RW, Acierno MJ. 2007. Evaluation of a combination of sodium hypochlorite and polyhexamethylene biguanide as an egg wash for red eared slider turtles (Trachemys scripta elegans) to suppress or eliminate Salmonella organisms on egg surfaces and in hatchlings. AJVR, 68(2): 158-159.

Pasmans F, Herdt PD, Haesebrouck F. 2002. Interactions of Salmonella enterica serovar munchen with macrophages of the turtle Trachemys scripta scripta. Dev. Comp. Immunol., 26(2): 295-300.

Pedersen K, Nielsen AML, Nordentoft S. Hammer AS. 2009. Serovars of Salmonella from captive reptiles.

Zoonoses and Public Health, 56: 239-240.

Pervical SL, Williams DW. 2004. Salmonella. Microbiology of Waterborne Disease (Second Edition). Academic Press, US.

Pickering LK, Baker C J, Kimberlin DW, Long SS. 2012. Red Book. Twenty-Ninth Edition.American Academy Pediatric, US.

Sa IVAD, Solari CA. 2001. Salmonella in brazilian and imported pet reptiles. Braz. J. Microbiol., 32: 293297. ISSN 1517-8382

Scallan E, Hoekstra RM, Angulo FJ, Tauxe RV, Widdowson MA, Roy SL, Jones JL, Griffin PM. (2011). Foodborne illness acquired in the united states- major pathogen. Emerg. Infect. Dis., eid1701.P11101.
Scharlau. 2009. Handbook of Microbiological Culture Media, Edition No. 10. Scharlau Chemie, Spain.

Schroter M, Roggentin P, Hofmann J, Speicher A, Laufs R, Mack D. 2004. Pet snakes as a reservoir for Salmonella enterica subsp. diarizonae (serogroup IIIb): a prospective study. Appl. Enviro. Microbiol., 70(1): 613-614.

Shane SM, Gilbert R, Harrington KS. 1990. Salmonella colonization in comercial pet turles (Pseudemys scripta elegans). Epidemiol. Infect., 105: 307-315.

Soedarto. 2012. Penyakit Zoonosis Manusia Ditularkan oleh Hewan. Sagung Seto, Jakarta.

Soeharsono. 2002. Penyakit Menular dari Hewan ke Manusia. Kanisius, Yogyakarta.

Srianta, Rinihapsari E. 2003. Deteksi Salmonella pada nasi goreng yang disediakan oleh restoran kereta api kelas ekonomi. J. Teknol dan Industri Pakan, 17(3): 253-254.

Su LH dan Chiu CH. 2007. Salmonella: clinical importance and evolution of nomenclature. Chang Gung Med J., 30(3): 210-212.

Tauxe RV, Perez JGR, Wells JG, Blake PA. 1985.Turtleassociated salmonellosis in Puerto Rico. JAMA, 254(2): 237-238.

Ternhag A, Torner A, Ekdahl K, Giesecke J. 2006. Salmonella associated death, Sweden, 1997-2003. Emerg. Infect. Dis., 12(2): 336-337.

Tille PM. 2017. Bailey \& Scott's Diagnostic Microbiology. Fourteenth Edition. Elsevier, US.

USFDA. CFR - Code of Federal Regulations Title 21. Turtles intrastate and interstate requirements.21 C.F.R. Sect. 1240.62 (revised April 1, 2019) [cited 2019 Apr 1].

White DG, Zhao S, Sudler R, Ayers S, Friedman S, Chen S, McDermott PF, McDermott S, Wagner DD, Meng, J. 2001. Salmonella from retail ground meats. Engl. J. Med., 345: 1147-1148.

Wikstrom VO, Fernstrom LL, Melin L, Boqvist S. 2014. Salmonella isolated from individual reptiles and enviromental samples from terraria inprivate households in Sweden. Acta Vet. Scand., 56(7): 1-2.

Williams LP, Helsdon HL. 1965. Pet turtle as a cause of human salmonellosis. JAMA, 192(5): 349-350.

Williams MPM. 2009. Indole Test Protocol. American Society for Microbiology, US.

Winn W, Allen SD, Allen S, Janda W, Koneman EW, Schreckenberger PC, Procop GW, Woods GL. 2006. Koneman's Color Atlas and Textbook of Diagnostic Microbiology. Baltimore, MD: Lippincott Williams \& Wilkins, 6.

Woodward D L, Khakhria R, Johnson WM. 1997. Human salmonellosis associated with exotic pets. J. Clin. Microbiol., 35(11): 2786-2790.

Yennie Y, Rizky A, Tri H K. 2017. Keberadaan danmultiresistensi antibiotic Salmonella spp. dari produk perikanan segar di wilayah DKI Jakarta dan Bogor. JPB Kelautan dan Perikanan, 12(1): 79-85. 